RASA UŠPALYTĖ-VITKŪNIENĖ, Ph.D. ${ }^{1}$

(Corresponding author)

E-mail: rasa.uspalyte@vgtu.lt

EDITA ŠARKIENE், Ph.D. ${ }^{1}$

E-mail: edita.sarkiene@vgtu.lt

DAIVA ŽILIONIENE், Ph.D. ${ }^{1}$

E-mail: daiva.zilioniene@vgtu.lt

${ }^{1}$ Vilnius Gediminas Technical University

Saulètekio av. 11, LT-10223 Vilnius, Lithuania
Traffic in the Cities

Preliminary Communication

Submitted: 29 Jan. 2019

Accepted: 14 Nov. 2019

\title{
MULTI-CRITERIA ANALYSIS OF INDICATORS OF THE PUBLIC TRANSPORT INFRASTRUCTURE
}

\section{ABSTRACT}

Public transport is a key element of sustainable transport in medium and large cities. Therefore, it is important that city residents want to use it. This paper aims to determine the criteria of the public transport infrastructure which have the most influence on passenger satisfaction with the public transport system. The criteria of public transport infrastructure of stops, vehicles, and route network were analysed. The primary attention was focused on rating these criteria from the most to the least important one. The analysis of scientific papers, specialized literature, Europe Union regulations, Lithuanian legislation, and recommendations were used to explore the necessary criteria that have a significant effect on the popularity of public transport, its functionality and gives a reference on how to raise the willingness of the citizens to use public transport. The experts (14 experts were involved) and social surveys (440 respondents were involved) were used to identify the evaluation criteria of public transport infrastructure and to investigate the state of these criteria. These criteria were grouped into three larger groups according to their nature (public transport infrastructure of stops, vehicles and route network) and were rated and prioritized by the multi-criteria analysis. The results reflect the priorities of criteria parameters of public transport infrastructure. The results show that when investing in public transport infrastructure, the main priority should be attributed to the infrastructure elements, such as public transport priority in the streets, then shelters, lighting, cleanness of bus stops and vehicles, which are physically appreciable. These parameters have the most significant impact on improving the level of service of public transport infrastructure in urban areas.

\section{KEY WORDS}

public transport infrastructure; priority; bus stops lighting; satisfaction; multi-criteria analysis;

\section{INTRODUCTION}

The growth of population and cities influence the development and improvement of public transport services. It had been done to meet the growing human needs and to avoid the problems caused by the increasing traffic flows. The rise of the living standard of the population poses a threat to the priority of public transport, i.e. more people choose private transport, which is faster, more comfortable, and more convenient. The number of cars per inhabitant in Lithuania is continually increasing. In order to maintain a strong position of public transport in the urban transport system, the state must ensure that the system is reliable, convenient, and attractive to the city residents.

The state encourages the use of public transport as often as possible to reduce transport congestion, noise, air pollution and social exclusion. The municipality emphasizes the need for a city to have a modern and balanced transport system that has a positive impact on the urban social and economic life, to ensure environmental quality and traffic safety. The offered quality of service (Level of Service - LOS) that consists of traffic conditions and passenger transportation determines the demand for public transport [1]. The Level of Service is the result of improvement, combination and practice of the indicators of public transport infrastructure as only a sustainable transport system meets the user needs and attracts more passengers. Chowdhury et al. [2] did the analysis on public transport users' and policy makers' perceptions of integrated public transport systems. This analysis showed that most policy makers and users, who frequently use the PT system, value network integration the most. Fares 
and ticketing were identified to be an important attribute by all three clusters of PT users. The economists Francis and Elliot [3] point out in their paper that it is important to analyse the need and benefit of an investment before investing. Only then will the investments have the greatest impact.

The role of public transport is essential in the accessibility of residential quarters, workplaces or leisure centres. With a rapidly developing city, the infrastructure of public transport must also keep pace [4]. In this way, there are needs for increased infrastructure investments that many cities do not have in many cases. Each year there are millions to be invested in public transport infrastructure development and modernisation of the public transport system, but people are still more likely to choose private cars. The lack of information on the importance and priority of public transport infrastructure indicators is one of the reasons for this phenomenon, i.e. there are investments in the development of irrelevant facilities and consequently the reduction of the number of funds for other needs that perhaps are significant. The attractive and accessible public transport system, which accumulates a significant part of the citizens who would use public transport instead of private cars for city trips, is created if public transport infrastructure criteria are arranged according to the importance based on the priorities that are set by the users of public transport. It is essential to understand which criterion is more or less necessary for the user, i.e. which of these criteria have the most influence on the user satisfaction or dissatisfaction with public transport. It is necessary to analyse and evaluate the criteria that make up the public transport infrastructure by applying Multi-Criteria Decision Analysis (MCDA) to reveal the current state of the public transport infrastructure.

This paper aims to determine these criteria of the public transport infrastructure, which have the most influence on the passenger satisfaction with the public transport system, i.e. for direct investments in public transport infrastructure and essential perception of LOS of the public transport.

\section{LITERATURE REVIEW}

Public transport with the possibility of enabling the European Union (EU) to meet the requirements for the movement and supply is one of the most essential services of general interest. This area is of particular importance for strengthening the social, economic and territorial cohesion of the EU. The scientists Burkauskas and Susnienè [5] distinguish five public transport objectives in the Lithuanian transport policy (Figure 1). It is important to note that only in the case of qualitative changes in public transport lies the benefit to all the interested parties, i.e. municipality, passenger transport companies, passengers and the community. The quality of the transportation and innovations leads to a positive image of public transport, and only a positive image encourages people to use public transport instead of private transport.

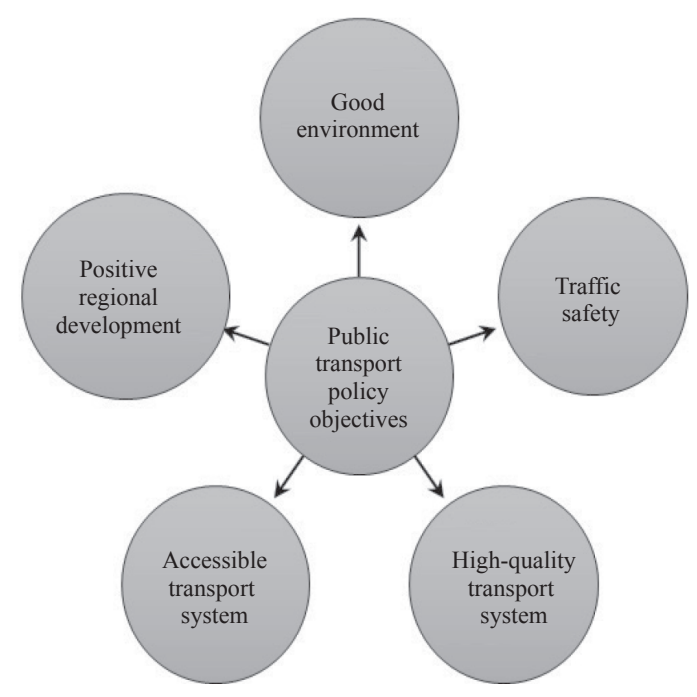

Figure 1 - Objectives of public transport policy in Lithuania [5]

Frequently, when improving the public transport system, the routes are changed in the city. Advanced public transport modes are introduced, but the existing infrastructure is unfairly forgotten. Only by changing and renovating the infrastructure, is it possible to raise the value of public transport system and the willingness to use it. Many scientists $[4,6-10,12-14]$ have already studied the impact of various elements of infrastructure on the public transport system and the passenger satisfaction with it. The overview of these scientific studies was carried out to select the elements which hereafter are subjected to the multi-criteria analysis of the public transport system.

Rational locations of stops in the bus route layout and the service frequency are sufficient to be a condition of sustainable public transport system that makes a significant impact on the quality of passenger service. The selection of the optimal distances between stops helps to save passenger time and increase the operating speed of the vehicles [6]. 
The public transport route network with the layout of periodical bus stops allows passengers to walk the short distances home $\leftrightarrow$ stop, or workplace $\leftrightarrow$ stop. People are attracted to use public transport, as they save travel time on a proper stop. It is crucial that a dense network of stops interfering with traffic (in mixed lanes) slows down the traffic flows. Also, the losses in speed of public transport, causing passengers to stay longer in the vehicle and causing higher risk of accidents due to manoeuvring to or from the stops, increases the transportation costs due to higher fuel consumption of buses [7, 8]. The Sydney University specialists in the transport systems note that it is no less important to take into account the demographic indicators. For example, in areas where there are more elder adults or fewer private cars, the distance to the stop should be shorter and vice versa [9]. Thus, the disabled people (especially those using wheelchairs) self-use public transport only when a low-floor bus or trolleybus arrive at the stop. The research results by Verseckienè et al. [10] show that only $30 \%$ of the transport system has been adapted for the disabled people. Tyler and Caiaffa [11] from the University College of London, argue that public transport stops should be designed in such a way as to be accessible for all the users of public transport.

Key points by Boyle [12] are that there are a pavilion, practical access to the kerb, pedestrian accessibility, street design, passenger information, comfort and accessibility for the disabled passengers, road or kerb design adapted to vehicles. One of the more significant factors by Newton [13] are the lighting of the stops and zones to access them.

The public transport network infrastructure and bus lanes were studied based on the research of Agrawal, Goldman and Hannaford, specialists from the Norman Y. Mineta International Institute for Surface Transportation Policy Studies (MTI) [14] focusing on separate bus lanes in the USA and the UK, as well as the Bus Rapid Transit (BRT) system. The research results show that the BRT system strongly enhances the image of public transport and strengthens its competitiveness with private cars. The research that also approved of this tendency was done by the Norwegian [15] and Spanish [16] specialists. Viegas and $\mathrm{Lu}$ [17] highlighted that even if it is impossible to install a full BRT system, the public transport priority should be maximally integrated into the street network.
"A" bus lanes ensure the priority for public transport on the street sections and intersections. These measures increase the average operating speed and create a higher LOS in public transport on the main routes [18, 19]. Agrawal et al. [14] indicate that when the yellow line and neon signs mark the "A" bus lane (extra lane), another motor vehicle is allowed to use it, but it is not allowed to stop and stay on this extra lane. For drivers who do not comply with this requirement and leave the motor vehicle on the extra lane, the penalties are imposed (the motor vehicle is towed away, there is financial penalty) to ensure efficient bus traffic flow on the extra lane.

The characteristics of public transport also affect the priority of passenger travel and, according to the studies carried out in Belgrade, this is due to the condition and the age of the motor vehicles, and even their fuel type [20].

Lighting and video cameras increase the passenger safety in public transport. Newton [13] did the investigation to find out what types of crime are common in public transport. It was found that both passengers and the public transport staff became victims. Often, there are cases of vandalism when the elements of a motor vehicle are destroyed [13].

\section{CRITERIA OF PUBLIC TRANSPORT INFRASTRUCTURE}

The analysis of public transport infrastructure identified the criteria which have a significant influence on the LOS conception of this mode of transport. These criteria were summarized and divided into three groups: the infrastructure of public transport stops, the infrastructure of public transport vehicles and the infrastructure of public transport route network (Table 1).

Public transport provides passenger services on scheduled routes, but it is clear that the public transport system has a sophisticated infrastructure consisting of various criteria, ranging from bus stops and their facilities to extra bus lanes. The infrastructure, in its general meaning combines interconnected structural elements that enable or support the entire structure and its functioning. The public transport infrastructure consists of stops and a transport network, as well as of public vehicles. Public vehicles are an essential component of the public transport system without which the system would be inoperable. The appearance, interior comfort and technical condition of the motor vehicle influence both the passenger opinion and choice. 
Table 1 - Selected criteria of public transport infrastructure

\begin{tabular}{|c|c|}
\hline \multirow{11}{*}{ 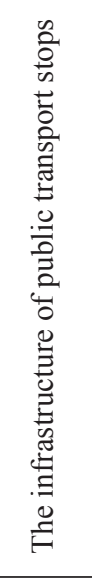 } & $\begin{array}{l}\text { Passenger shelter } \\
\text { (protecting from rain, wind, snow) }\end{array}$ \\
\hline & Cleanness \\
\hline & Possibility to have a seat \\
\hline & Lighting \\
\hline & Security cameras \\
\hline & Availability of timetable \\
\hline & Real-time display \\
\hline & Wi-Fi \\
\hline & Adaptation to disabled people \\
\hline & Ticket sale and distribution points \\
\hline & Map of the public transport network \\
\hline \multirow{10}{*}{ 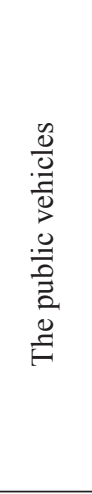 } & Possibility to have a seat \\
\hline & Heating, conditioning, ventilation \\
\hline & Cleanness \\
\hline & Interior design \\
\hline & Age of vehicle \\
\hline & Technical condition \\
\hline & Possibility to carry a bike \\
\hline & Audio or video notification \\
\hline & Wi-Fi \\
\hline & Adaptation to disabled people \\
\hline \multirow{5}{*}{ 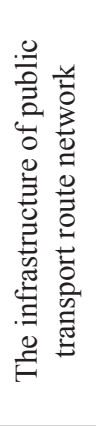 } & Multimodal compatibility (P\&R, B\&R) \\
\hline & $\begin{array}{l}\text { The system of ticket sale and distribution } \\
\text { (flexible, integrated, open, modern) }\end{array}$ \\
\hline & $\begin{array}{l}\text { Distance to a bus stop } \\
\text { (distance from home, workplace) }\end{array}$ \\
\hline & Bus lanes \\
\hline & $\begin{array}{l}\text { Information } \\
\text { (quick and flexible system of information about } \\
\text { routes and timetables, network and work time } \\
\text { changes at bus stops, on the internet, other). }\end{array}$ \\
\hline
\end{tabular}

\section{MULTI-CRITERIA ANALYSIS}

Arditi and Gunaydin's [21] and Yoon and Hwang's [22] methods and recommendations were used to describe the multi-criteria analysis and calculate the results.

The multi-criteria analysis was carried out by interviewing 14 respondents from different European cities with the scientific experience in the transport field of at least five years. The experts were chosen to represent the public transport operators, planners, and scientists involved in the field of public transport. The City of Vilnius (Lithuania) was chosen as the case study area. The significance and the existing situation of the expert surveys were made to find out the expert opinions about the priority criteria of public transport. The results of the expert surveys show the priority criteria of public transport quality based on the theoretical and practical knowledge or assumptions, and the apparent priority of criteria that make a significant contribution to satisfy the public transport users in the public transport system.

In this case, the significance level was given to the expert depending on their experience, i.e. the criterion (significance level) is equal to 1.00 for an expert with more than 15 years of experience, $0.8-$ from 10 to 15 years of experience, and 0.6 - from 5 to 10 years of experience.

After the examination, the $t_{j k}$ evaluation sets were processed statistically. Therefore, the average value of criterion $\bar{t}_{j}$ is determined by Equations 1 or 2 :

$$
\overline{t_{j}}=\frac{\sum_{k=1}^{r} w_{k} t_{j k}}{\sum_{k=1}^{r} w_{k}}
$$

or

$$
\overline{t_{j}}=\frac{\sum_{k=1}^{r} t_{j k}}{r}
$$

where $w_{k}$ - significance level of the $k$-th expert; $t_{j k}$ - estimation of the $j$-th criterion made by the $k$-th expert; $r$-number of experts.

Variation (Equation 3) characterizes expertise reliability

$\beta_{j}=\sigma: \overline{t_{j}}$

where $\sigma$-average square variance of the expert estimate, determined by Equation 4:

$\sigma^{2}=\frac{1}{r-1} \sum_{k-1}^{r}\left(t_{k}-\overline{t_{j}}\right)^{2}$

where $\sigma^{2}$ - the variance of the expert estimates.

Reliability of expertise is expressed by the Kendall coefficient of concordance that describes the level of consensus among the estimates of individual experts:

$$
W=\frac{12 S}{r^{2}\left(n^{3}-n\right)-r \sum_{k=1}^{r} T_{k}}
$$

where $S$ - sum of the squared deviations of the results of each estimate criterion by the expert

$$
S=\sum_{j=1}^{n}\left[\sum_{k=1}^{r} t_{j k}-\frac{1}{n} \sum_{j=1}^{n} \sum_{k=1}^{r} t_{j k}\right]^{2}
$$

and

$T_{k}=\sum_{l=1}^{H_{l}}\left(h_{l}^{3}-h_{l}\right)$ 
where $T_{k}$ - indicator of ranks correlated in the $k$-th ranking; $H_{l}$ - number of equal rank groups in the $k$-th ranking; $h_{l}$ - number of equal ranks in the first group of correlated ranks estimated by the $k$-th expert; $t_{j k}-$ rank attached to the $j$-th criterion by the $k$-th expert; $r$ - number of experts; $n$-number of estimate criteria.

If there are no correlated ranks, the Kendall coefficient of concordance is determined by Equation 8: $W=\frac{12 S}{r^{2}\left(n^{3}-n\right)}$

Equation 9 determines the significance of the Kendall coefficient of concordance:

$$
\chi^{2}=\frac{12 S}{r n(n+1)-\frac{1}{n-1} \sum_{k=1}^{r} T_{k}}
$$

If $\chi^{2}>\chi_{\text {table }}^{2}$, the hypothesis of expert ranking is accepted. Otherwise, if $\chi^{2}<\chi_{\text {table }}^{2}$, it is assumed that there is no overall agreement among the expert opinions and the hypothesis is rejected (Figure 2) $[21,22]$.

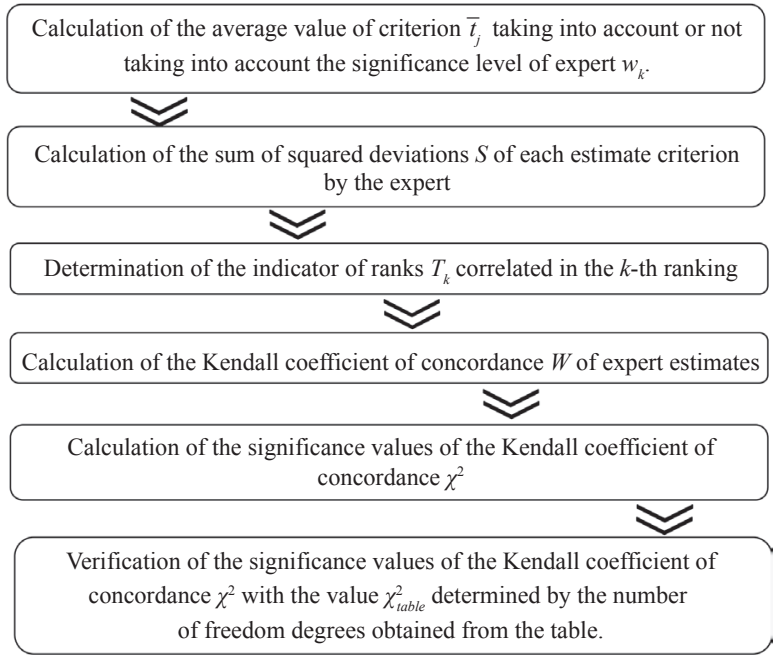

Figure 2-The scheme of the expert method

\section{THE SIGNIFICANCE OF PUBLIC TRANSPORT CRITERIA}

The expert evaluation of the significance (weight) of each criterion in its group was determined, and the weight coefficients multiplied by the normalized matrix. Then, the best option was selected by calculating the total distance of each comparative variant to the best and the worst solutions. Calculations made in all three criteria groups showed that the value of $\chi^{2}>$ $\chi_{\text {table, }}^{2}$, which means that the expert hypothetical estimations are consistent and acceptable.

Stop shelter and timetable are the most significant criteria of the infrastructure of public transport stops (Figure 3). The least value was attributed to the wireless Internet, security cameras or distance to the points of ticket sale and distribution. Even the reason for these two criteria is irrelevant to the technological development, i.e. growing mobile Internet and increasing the number of public transport services to the online space, such as online tickets. The map of the public transport network or the real-time display is attributed to the criterion of less significance.

The most significant criteria are those which are physically assessed by passengers while waiting for the vehicle. The physical criteria of the vehicle, i.e. cleanliness, heating, conditioning or ventilation, as well as the technical condition of vehicles also remained as the most significant criteria in the group of criteria for public vehicles (Figure 4). Additional services, such as the wireless Internet or the possibility to carry a bike, as well as the beautiful view from the vehicle, were assessed as the least significant ones. The interior design or age of the vehicle are insignificant as long as the vehicle is in good technical condition and clean.

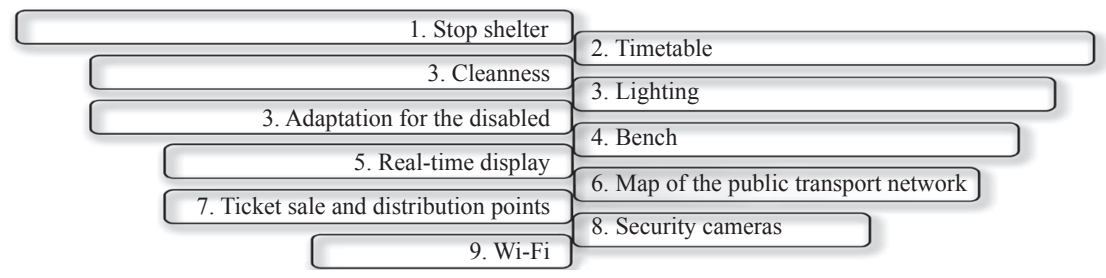

Figure 3 - The significance of the criteria of the infrastructure of public transport stops

3. Heating, conditioning, ventilation

Figure 4 - The significance of the criteria for public vehicles 


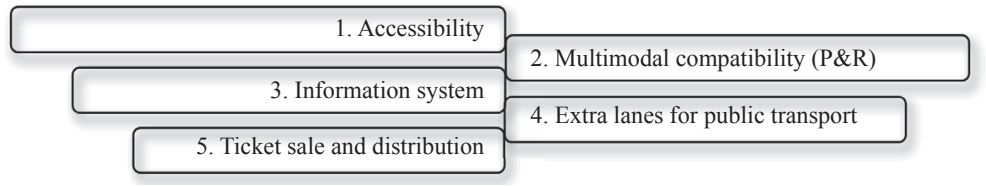

Figure 5 - The significance of the criteria of the public transport network infrastructure

In the last group of the criteria of the public transport network infrastructure (Figure 5), the most significant criteria were the accessibility of bus stops and multimodal compatibility. Both criteria interpret the accessibility of public transport for all road users; those coming on foot from home and those coming from other vehicles (bicycles, cars) to the point of public transport. The ticket sale and distribution system are assessed as the least significant criteria in the infrastructure of the public transport network.

\section{ESTIMATIONS OF EXPERTS AND USERS}

In order to confirm the credibility of the expert opinion, a population survey was conducted. They were asked about the main criteria for public transport infrastructure that influence their choice of public transport for travel. A public survey was carried out to verify the results of the expert multi-criteria analysis. The questionnaire was used in the survey. The survey involved 440 respondents, who were selected in public places like shopping centres in order to include all types of users. The results of multi-criteria analysis and the public survey showed that the estimations of experts and users coincide with both the general priorities of public transport and the comparison of specific criteria. In summary, both groups specified that the speed of travel (which is achieved by giving priority to public transport by implementing bus lanes and stops accessibility) is the main priority of public transport. For the present, comfort (which includes the possibility to sit, heating/ventilation system, adaptation for the disabled) is the second priority, and the cost (which is influenced by the age of the vehicle, the design, the additional services) of the journey is only the third priority of public transport.

The information system and lighting remained significant in both cases in the infrastructure of public transport stops (Figure 6). The adaptation to the needs of the disabled arises as a little significant criterion compared to others even in the results of multi-criteria analysis based on expert estimates. This shows that experts seek to raise the quality of public transport first and foremost for the vast majority of consumers, forgetting about its social function.

Evaluation of the technical facilities of vehicles showed that the most significant criteria in both cases were their technical condition and the vehicle air regulation system. First, it would be necessary to invest in the development of these technical facilities of vehicles to make passengers more likely to feel an increased LOS of the public transport. It is interesting that the results of vehicle assessment did not include the criteria which provide real comfort, i.e. the age of the vehicle or the interior design. Such an attitude makes it clear that, first of all, public transport is a mode of mobility.

Some estimations between experts and social opinions differed slightly in the evaluation of criteria of the infrastructure of the public transport route network. The distance to the public transport stop and the possibility to change a vehicle are the main criteria based on a multi-criteria analysis. However, in the public survey, most respondents emphasized the need for as many as possible extra bus lanes in public transport. Such an estimation indicates that for the users the speed is one of the most significant criteria of public transport.

\section{CONCLUSION}

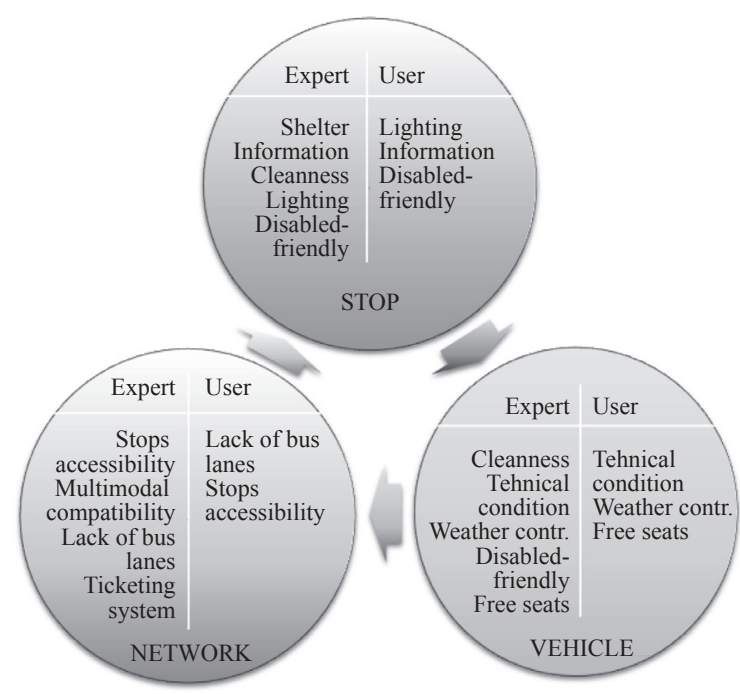

Figure 6-Comparison of the results of multi-criteria analysis and public survey 
The research aimed to find out what makes the most significant effect on passenger satisfaction with public transport system, seeking well-targeted investments in public transport infrastructure and the essential effect on the people's understanding about the level of service of public transport.

Having an analysis of public transport infrastructure by multi-criteria analysis and having verified the results with the help of public survey, the main conclusion is that the opinions of experts and users coincide. Consequently, speed is the main priority of public transport. For the present, comfort is the second priority, and the cost of the journey is only a third priority of public transport.

It is advisable to apply the results obtained by multi-criteria analysis and the public survey, to develop the public transport system in every city. The results show that when investing in public transport infrastructure, the main priority should be attributed to the infrastructure elements, such as the shelter, lighting, cleanness of bus stops and vehicles, which are physically appreciable. First, to improve the public transport network, it is necessary to direct investments into the assurance of competitive speed that allows the public transport to better compete with other vehicles (with bicycles on short distances, with private cars on longer distances). By investing in these criteria, the satisfaction with the public transport system grows faster and has a more significant impact on the users.

\author{
Dr. RASA UŠPALYTÉ-VITKŪNIENE் $\dot{1}^{1}$ \\ E-mail: rasa.uspalyte@vgtu.lt \\ Dr. EDITA Š SRKIEN $\dot{\mathbf{E}}^{1}$ \\ E-mail: edita.sarkiene@vgtu.lt \\ Dr. DAIVA ŽILIONIENÉ ${ }^{1}$ \\ E-mail: daiva.zilioniene@vgtu.lt \\ ${ }^{1}$ Vilniaus Gedimino Technikos Universitetas \\ Saulètekio al. 11, LT-10223 Vilnius, Lietuva
}

\section{VIEŠOJO TRANSPORTO INFRASTRUKTUEROS KRITERIJU DAUGIAKRITERINE் ANALIZE்}

\section{ABSTRAKTAS}

Viešasis transportas yra pagrindinis darnaus transporto elementas vidutiniuose ir dideliuose miestuose. Todèl svarbu, kad miesto gyventojai norètu juo naudotis. Šiuo straipsniu siekiama nustatyti tuos viešojo transporto infrastruktūros kriterijus, kurie daro didžiausia itaka keleiviu pasitenkinimui viešojo transporto sistema. Išanalizuoti stoteliu, transporto priemoniu ir maršrutu tinklo viešojo transporto infrastruktūros kriterijai. Pagrindinis dèmesys buvo skiriamas šiu kriteriju ivertinimui išskiriant svarbiausius. Išanalizuoti svarbiausi kriterijai, turintys reikšminga poveiki viešojo transporto populiarumui, jo funkcionalumui ir pateiktos prioritetinès kryptys, kaip kelti viešojo transporto patraukluma, analizuoti moksliniai darbai, specializuota literatūra, Europos Sajungos reglamentai, Lietuvos istatymai ir rekomendacijos. Viešojo transporto infrastruktüros vertinimo kriterijams nustatyti ir šiu kriteriju būklei ištirti buvo naudojamos ekspertine analizé (dalyvavo 14 ekspertu) ir socialinès apklausos (dalyvavo 440 respondentu). Šie kriterijai buvo suskirstyti i tris didesnes grupes pagal ju pobūdi (stoteliu, transporto priemoniu ir maršrutu tinklo viešojo transporto infrastruktūra), tolesniam etape daugiakriterinès analizés būdu kriterijai buvo ịvertinti ir jiems suteikti prioritetai. Rezultatai rodo, kad investuojant i viešojo transporto infrastruktüra, svarbiausias prioritetas turètu büti teikiamas infrastruktūros elementams, tokiems kaip viešojo transporto prioritetas gatvése, stoteliu aprūpinimas pastogemis, apšvietimu, autobusu stoteliu ir transporto priemoniu švarumas. Šie parametrai daro didžiausia ịtaka gerinant viešojo transporto infrastruktūros paslaugu lygi miesto teritorijose.

\section{RAKTINIAI ŽODŽIAI}

viešojo transporto infrastruktūra; prioritetas; viešojo transporto stotelès; stoteliu apšvietimas; pasitenkinimas; daugiakriterine analize;

\section{REFERENCES}

[1] Uspalyte-Vitkuniene R, Vitkunas S. Public Transport Systems in Baltic States. In: Proceedings of the $7^{\text {th }}$ International Conference of Environmental Engineering, 22-23 May 2008, Vilnius, Lithuania, Vol. 3; 2008. p. 1081-1086.

[2] Chowdhury S, Hadas Y, Gonzalez VA, Schot B. Public transport users' and policy makers' perceptions of integrated public transport systems. Transport Policy. 2018;61: 75-83. Available from: doi:10.1016/j.tranpol.2017.10.001

[3] Francis R, Elliott D. Infrastructure funding: does it matter where the money comes from? 2019. 25 p. Available from: https://www.itf-oecd.org/sites/default/files/docs/ infrastructure-funding-where-money-comes-from.pdf [Accessed 15 ${ }^{\text {th }}$ Sep. 2019].

[4] Karou S, Hull A. Accessibility modelling: predicting the impact of planned transport infrastructure on accessibility patterns in Edinburgh, UK. Journal of Transport Geography. 2014;35: 1-11.

[5] Susniene D, Jurkauskas A. Stakeholder Approach in the Management of Public Transport Companies. Transport. 2008;23(3): 214-220. Available from: doi:10.3846/16484142.2008.23.214-220

[6] Ceder AA, Butcher M, Wang L. Optimization of bus stop placement for routes on uneven topography. Transportation Research Part B: Methodological. 2015;74: 40-61. Available from: doi:10.1016/j.trb.2015.01.006 
[7] Li H, Bertini RL. Optimal bus stop spacing for minimizing transit operation cost. Traffic and Transportation Studies. 2008;51: 553-564. Available from: doi:10.1061/40995(322)51

[8] Li H. Assessment of an optimal bus stop spacing model using high resolution archived stop-level dana. MSc thesis. Portland State University; 2011.

[9] Daniels R, Mulley C. Explaining walking distance to public transport: The dominance of public transport supply. Journal of Transport and Land Use. 2013;6(2): 5-20. Available from: doi:10.5198/jtlu.v6i2.308

[10] Verseckienė A, Meškauskas V, Batarlienė N. Urban Public Transport Accessibility for People with Movement Disorders: The Case Study of Vilnius. Procedia Engineering. 2016;134: 48-56. Available from: doi:10.1016/ j.proeng.2016.01.038

[11] Tyler N, Caiaffa M. Design of Fully Accessible Bus Stops. Infrastructure Elements for Buses and Drivers. In: Proceedings of AET European Transport Conference, 1 January 1999 Cambridge; 1999. p. 433-439. Available from: http://etcproceedings.org/paper/design-of-fullyaccessible-bus-stops-infrastructure-elements-for-buses-and-dri [Accessed 28 ${ }^{\text {th }}$ Jan. 2017].

[12] Boyle DK. Better On-Street Bus Stops. Transportation research, Report number: Project J-7 SA-35, 2015. Available from: http://www.trb.org/Main/Blurbs/172376.aspx [Accessed 22 $2^{\text {th }}$ Sept. 2017].

[13] Newton A. Crime on public transport. Encyclopedia of criminology and criminal justice. 2014: 709-720. Available from: doi:10.1007/978-1-4614-5690-2_301

[14] Agrawal AW, Goldman T, Hannaford N. Shared-use bus priority lanes on city streets: Case studies in design and management. Mineta Transportation Institute, No. CA-MTI-12-2606, 2012. Available from: https://scholarworks.sjsu.edu/cgi/viewcontent.cgi?referer=https:// scholar.google.com/\&httpsredir=1\&article=1026\&context $=$ mti_publications

[15] Siedler CE. Can bus rapid transit be a sustainable means of public transport in fast growing cities? Empirical evidence in the case of Oslo. Transportation Research Procedia. 2014;1(1): 109-120. Available from: doi:10.1016/j.trpro.2014.07.012

[16] Canales C, Estrada Romeu MÁ, Thorson Bofarull L, Robusté Antón F. Public transport policies in Europe: implementing bus rapid transit systems in major European cities. In: Proceedings of European Transport Conference 2006. Association for European Transport; 2006; p. 1-15. Available from: https://upcommons.upc.edu/bitstream/handle/2117/15615/2443737.pdf [Accessed $15^{\text {th }}$ Apr. 2018].

[17] Viegas J, Lu B. The intermittent bus lane signals setting within an area. Transportation Research Part C: Emerging Technologies. 2004;12(6): 453-469. Available from: doi:10.1016/j.trc.2004.07.005

[18] Ušpalytè-Vitkūnienè R. Modelling and development of town public transport network (on example of Vilnius city). PhD thesis. Vilnius Gediminas Technical University; 2006.

[19] Cats O, Jenelius E. Dynamic vulnerability analysis of public transport networks: mitigation effects of real-time information. Networks and Spatial Economics. 2014;14(3-4): 435-463. Available from: doi:10.1007/ s11067-014-9237-7

[20] Petrović J, Ivković I, Vujačić I, Žeželj S. Possibilities of buses on alternative fuel in public urban transport in Belgrade. Technological and Economic Development of Economy. 2009;15(1): 78-89. Available from: doi:10.3846/1392-8619.2009.15.78-89

[21] Arditi D, Gunaydin HM. Perceptions of process quality in building projects. Journal of Management in Engineering. 1999;15(2): 43-53. Available from: doi:10.1061/ (ASCE)0742-597X(1999)15:2(43)

[22] Yoon K, Hwang CL. TOPSIS (technique for order preference by similarity to ideal solution)-a multiple attribute decision making, w: Multiple attribute decision makingmethods and applications, a state-of-the-art survey. Berlin: Springer Verlag; 1981; p. 128-140. 